June 72008

\title{
Implications of the 'Bread and Peace' Model for the 2008 US Presidential Election
}

Douglas A. Hibbs, Jr.

CEFOS, Gothenburg University, Box 72040530 Gothenburg, Sweden

douglas@douglas-hibbs.com www.douglas-hibbs.com

Forthcoming in Public Choice, September 2008

\begin{abstract}
Presidential election outcomes are well explained by just two objectively measured fundamental determinants: (1) weighted-average growth of per capita real personal disposable income over the term, and (2) cumulative US military fatalities owing to unprovoked, hostile deployments of American armed forces in foreign conflicts. The US economy weakened at the beginning of 2008 and average per capita real income growth probably will be only around $0.75 \%$ at Election Day. Moreover cumulative US military fatalities in Iraq will reach 4,300 or more. Given those fundamental conditions, the Bread and Peace model predicts a Republican two-party vote share centered on $48.2 \%$.
\end{abstract}




\section{Background}

My analysis of the fundamental determinants of aggregate presidential voting outcomes and their implications for the 2008 election draws upon research reported in my earlier Public Choice article (Hibbs 2000) $^{1}$ and in my unpublished 2007 paper "The Economy, the War in Iraq and the 2004 Presidential Election." ${ }^{2}$

The Bread and Peace model assumes that postwar American presidential elections should for the most part be interpreted as a sequence of referendums on the White House party's economic record. The incumbent party is punished for poor economic performance and rewarded for good performance. Economic performance is best measured by a weighted-average of quarterly growth rates of per capita real disposable personal income, computed from the election quarter back to the first full quarter of each presidential term. Growth of per capita real disposable personal income is the broadest single aggregate measure of changes in voters' economic well-being in as much as it includes income from all market sources, is adjusted for inflation, taxes, government transfer payments and population growth, and tends to move with changes in unemployment.

The only additional factor systematically affecting postwar aggregate votes for president is US military fatalities owing to unprovoked, hostile deployments of American armed forces in foreign conflicts not sanctioned by a formal Congressional declaration of war - namely the American military interventions in Korea, Vietnam and most recently Iraq. My research shows that the electoral penalties exacted by Korea, Vietnam and Iraq fall almost wholly on the party initiating the commitment of US forces - the Democrats for Korea and Vietnam, the Republicans for Iraq - and they are proportionate to the cumulative numbers of American military fatalities, adjusted for population size. Other factors of course influence presidential voting, sometimes dramatically, but they vary randomly from election to election. Because such events are idiosyncratic rather than systematic, they cannot be incorporated to the Bread and Peace model which aims to pin down quantitatively the impact of persistent fundamental determinants.

The Bread and Peace model is designed to explain presidential election outcomes in terms of objectively measured political-economic fundamentals rather than to predict optimally election results or to track them statistically after the fact. For those reasons the model includes no arbitrarily

1 The basic functional form of the economic factor in the Bread and Peace equation was first proposed in my earlier article (Hibbs 1982). I review the large literature on macroeconomic conditions and voting in (Hibbs 2006).

2 The 2007 paper is available at http://douglas-hibbs.com/HibbsArticles/QJPS_2007.pdf. It was rejected by the Quarterly Journal of Political Science as "unnecessarily acerbic" in its criticism of an article by William Nordhaus published in the same journal (Nordhaus 2006) that contrasted my model to various equations proposed by Nordhaus' Yale economics department colleague Ray Fair (http://fairmodel.econ.yale.edu/vote2008/index2.htm) . See the QJPS rejection history at http://douglas-hibbs.com/HibbsArticles/QJPS_History.pdf. 
coded dummy, trend, count, or switching variables which have no connection to objectively measured policies and performance affecting voters. ${ }^{3}$ Likewise the Bread and Peace model makes no use of pre-election poll readings of voter sentiments, preferences and opinions. Attitudinal variables are themselves affected by objective fundamentals and consequently they supply no insight into the root causes of voting behavior, even though they may provide good predictions of voting results. ${ }^{4}$ In fact the best predictions of presidential elections (along with other elections and other events) most likely are obtained from price data at betting sites like Intrade (www.intrade.com) where punters lay real money on the table. ${ }^{5}$

\section{The Bread and Peace Equation}

Estimation of the following simple nonlinear equation yields quantitative estimates of the effects on votes for president of per capita real income growth and the cumulative number of American military fatalities in Korea, Vietnam and Iraq:

$$
\text { Vote }_{t}=\alpha+\beta_{1}\left(\sum_{j=0}^{14} \lambda^{j} \Delta \ln R_{t-j}\left(1 / \sum_{j=0}^{14} \lambda^{j}\right)\right)+\beta_{2} \text { Fatalities }_{t}
$$

- Vote is the percentage share of the two-party vote for president received by the candidate of the incumbent party.

- $R$ is per capita disposable personal income deflated by the Consumer Price Index. $\Delta \ln R_{t}$ is the quarter-to-quarter percentage change expressed at annual rates, computed $\log \left(R_{t} / R_{t-1}\right) \cdot 400$. The weighted sum of annualized quarterly real income growth rates $\Delta \ln R_{t}+\lambda \ln \Delta R_{t-1}+\lambda^{2} \Delta \ln R_{t-2}+\ldots+\lambda^{14} \Delta \ln R_{t-14} \quad(0 \leq \lambda \leq 1) \quad$ runs from the election quarter back to the first full quarter of each presidential term. ${ }^{6}$ The sequence of over-theterm growth rates is divided through by the sum of the lag weights $\sum_{j=0}^{14} \lambda^{j}$ so that the

\footnotetext{
3 A prominent example is the equation currently favored by Ray Fair (http://fairmodel.econ.yale.edu/RAYFAIR/PDF/2006CHTM.HTM) - five of the seven regressors in Fair's equation are ad-hoc dummies, trends or counts. See (Bartels 1997) for a critical discussion of the ad-hoc use of such variables. 4 Leading examples of presidential election prediction equations using attitudinal variables are reviewed by (Wlezien and Erikson 2004).

5 According to (Erikson and Wlezien 2008) poll data on average outperform the Iowa Electronic Market betting data in forecasting presidential election outcomes between 1988 and 2004. The IEM market however is a university run operation with constrained betting (the limit is currently five hundred dollars per individual) and quite thin trading by comparison to commercial enterprises like Intrade.

6 At the election quarter the weight $\left(j=0, \lambda^{j}=1\right)$ is scaled down to $1 / 3$ because of the within-quarter date of presidential elections (the first Tuesday following the first Monday of November).
} 
coefficient $\beta_{1}$ represents the effect on the incumbent vote share of each percentage point of weighted-average annualized quarter-to-quarter real income growth sustained over the presidential term. As the weighting parameter $\lambda$ approaches a value of 1.0 the incumbent party vote share is affected by a simple average of per capita real income growth rates over the whole term; growth at the beginning of the term has the same electoral impact as growth just before the election. As $\lambda$ approaches zero only the election quarter growth rate affects votes for president. Values of $\lambda$ between 0 and 1 determine the relative political importance of real income growth rates just before the election as compared to growth rates earlier in the term.

- Fatalities denotes the cumulative number of American military fatalities per million US population in Korea, Vietnam and Iraq during the presidential terms preceding the 1952, 1964, 1968, 1976 and 2004 elections. $^{7}$

Table 1 reports nonlinear-least-squares estimates of the Bread and Peace equation for presidential elections spanning 1952-2004. The model was fit using data on population and disposable personal incomes from the Bureau of Economic Analysis (www.bea.gov) and consumer prices from the Department of Labor (www.stats.bls.gov), along with data on US military fatalities in Korea, Vietnam and Iraq originating with the US Department of Defense. ${ }^{8}$

According to the coefficient estimates in Table 1, each percentage point of growth in per capita real disposable personal income sustained over a presidential term boosts the in-party candidate's vote share by about 3.6 percentage points above a benchmark constant of approximately $46 \%$. The weighting parameter estimate $\hat{\lambda}=0.91$ implies that the real income growth rate in the last full quarter before an election ( $q 3$ of election years) has more than three times the electoral impact of income growth in the first full quarter of the term $\left(0.91 / 0.91^{14}=3.44\right)$. The fatalities coefficient estimate means that each 100 US military fatalities per million population owing to hostile deployments of US forces in unprovoked wars depresses the incumbent vote by about 5 percentage points.

\footnotetext{
7 Prior to 2004 my periodic applications of the Bread and Peace model did not scale cumulative US military fatalities to population. Yet the US had 158 million inhabitants at the time of the 1952 election and will have approximately 306 million at the 2008 election, so scaling fatalities to population makes good sense even though the quantitative effects implied by the scaled and un-scaled equations are very similar.

8 The BEA income data are from the May 292008 revision of the National Income and Product Accounts - the 2008q4 data are preliminary and are subject to revision (perhaps substantial) later. Military fatalities in Iraq are from www3.cnn.com/SPECIALS/2003/iraq/forces/casualties/interactive and www.icasualties.org/oif. Data on fatalities in Korea and Vietnam were obtained by the author from the National Defense University Library in Carlyle Pennsylvania. Stata program and data files for results in this article are available at http://www.douglashibbs.com/HibbsArticles/hibbs_downloadable.htm.
} 
Table 1. Bread and Peace Equation Estimates

\begin{tabular}{|c|c|c|c|}
\hline \multirow[t]{3}{*}{$\begin{array}{l}\text { Dependent variable: } \\
\text { incumbent two-party vote } \\
\text { share }(\%)\end{array}$} & \multicolumn{3}{|c|}{$\begin{array}{l}N=14 \\
\text { elections } \\
1952-2004\end{array}$} \\
\hline & $R^{2}=.87$ & Adj $R^{2}=.83$ & Root MSE $=2.38$ \\
\hline & $\underline{\text { coefficient estimate }}$ & $\underline{\text { std. error }}$ & p-value \\
\hline Constant $(\alpha)$ & 46.2 & 1.22 & .000 \\
\hline $\begin{array}{l}\text { Weighted-average } \\
\text { per capita real disposable } \\
\text { personal income growth } \\
\text { rate, } \%\left(\beta_{1}\right)\end{array}$ & 3.55 & 0.605 & .000 \\
\hline Lag weight $(\lambda)$ & 0.909 & 0.057 & .000 \\
\hline $\begin{array}{l}\text { US military fatalities per } \\
\text { million population }\left(\beta_{2}\right)\end{array}$ & -0.052 & 0.013 & .002 \\
\hline
\end{tabular}

The pronounced connection of two-party vote shares received by incumbent party candidates to weighted-average per capita real income growth rates over the term at postwar elections 1952-2004 is graphed in Figure 1. (Appendix Table A1 shows more statistics for each election.) Voting outcomes in 1952 and 1968 exhibit the biggest deviations from the regression prediction line - they register the effects of the second fundamental determinant of presidential voting: American military fatalities in unprovoked foreign wars.

High cumulative US military fatalities in Korea at the time of the 1952 election $(29,260$ or 190 per million population) and in Vietnam at the 1968 election (28,900 or 146 per million population) cost candidates of the incumbent Democratic party dearly, most likely causing Adlai Stevenson's loss to Dwight Eisenhower in 1952 and almost certainly causing Hubert Humphrey's loss to Richard Nixon in 1968. Absent America's interventions in the Korean and Vietnamese civil wars, the strong real income growth record prior to those elections easily should have kept the Democrats in the White House.

In principle, military fatalities due to discretionary American involvement in foreign conflicts were also relevant to the 1964, 1976 and 2004 election contests, but the impact on aggregate votes was negligible because the fatality numbers were small. At the 2004 election, for example, US military 
fatalities in Iraq stood at 1,130 (3.86 per million population) - too few to exert great negative effect on the vote for Bush. However by the time of the 2008 election US military fatalities will have quadrupled. Consequently, as I show ahead, Iraq will play a more important role in 2008 than in 2004.

Figure 1. Bread and Peace Voting in US Presidential Elections

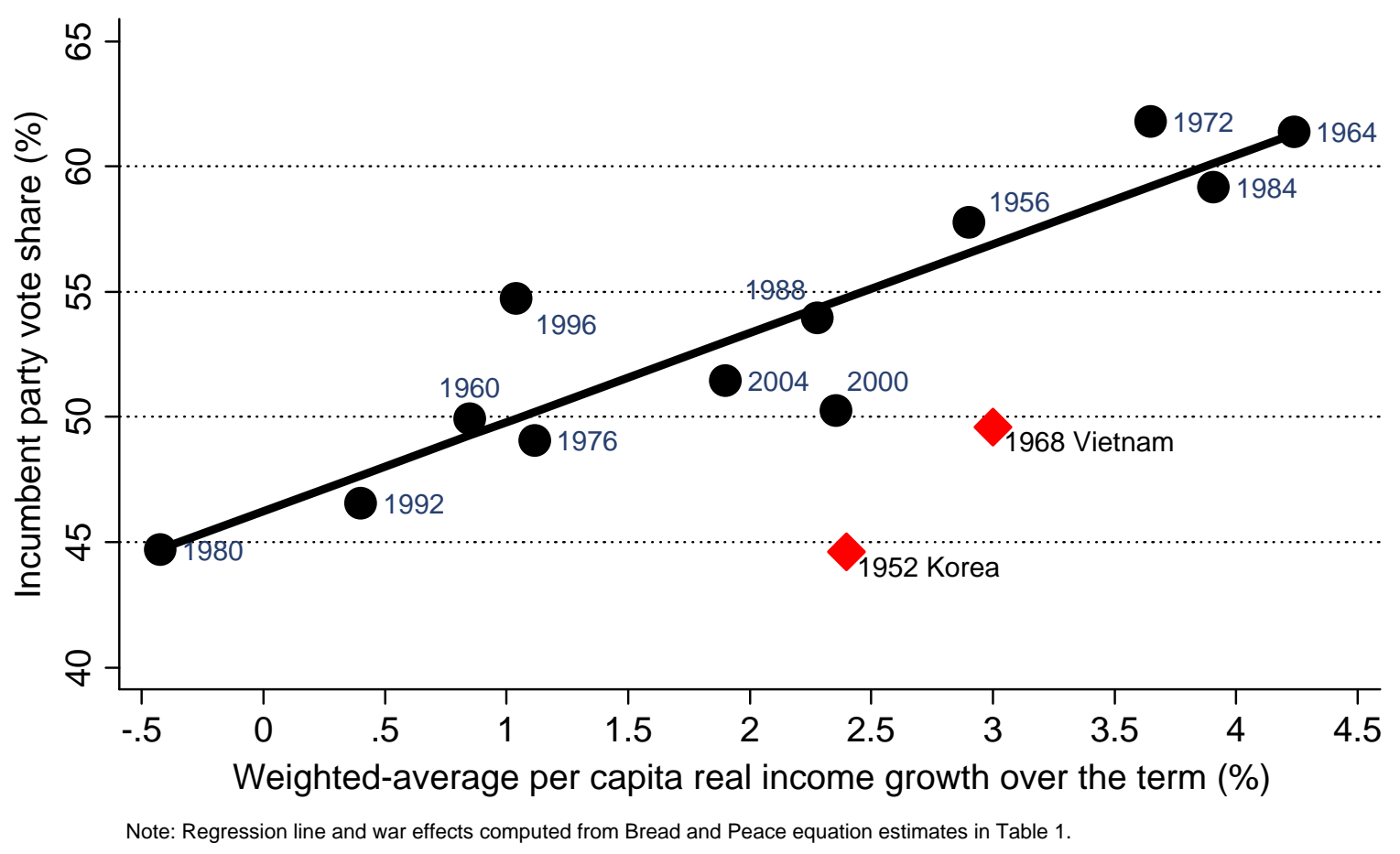

\section{The Economy, Iraq and the 2008 Election}

Republican fortunes in 2008 will depend on the severity of the US economic contraction now underway and the accumulation of US military fatalities in Iraq. Over the first full twelve quarters of President Bush's second term (2005q2 - 2008q1) the weighted-average growth rate of per capita real disposable personal income was 1.04\%, which although significantly below the postwar average of $1.8 \%$ is within striking distance of the performance necessary to keep the incumbent party in the White House. According to the Bread and Peace model other things being equal the incumbent party vote share reaches the break-even point of $50 \%$ at a weighted-average growth rate 
of just $1.07 \%{ }^{9}{ }^{9}$ However in 2008 "other things" are not going to be equal. At the beginning of 2008 the US economy weakened, perhaps drifting into recession. ${ }^{10}$ And at June 12008 cumulative US military fatalities in Iraq had reached 4,084. Both developments hurt Republican chances.

\subsection{Growth of Per Capita Real Disposable Personal Income}

Figure 2 shows the evolution of weighted-average growth of real incomes over the term along with various scenarios for real income growth during the last three quarters of 2008 . Fairly pessimistic scenarios are probable, notwithstanding the fiscal stimulus package passed by congress and signed into law by President Bush on February 132008 that will raise aggregate disposable income by about $1 \%$ in the half-year before the election. The relative sizes of the plot points for hypothetical 2008 growth rates reflect my reading of the tea leaves.

As indicated by Figure 2, I think real income growth rates near the postwar average of $1.8 \%$ are unlikely. 2008q2-2008q4 growth rates will probably be in the vicinity of $0 \%$, which at Election Day would yield an over the term weighted-average real growth performance in the vicinity of $0.75 \%$. According to the Bread and Peace model such a real income growth record by itself implies a relatively narrow victory for the out-party Democratic candidate (presumptively Barack Obama) over the incumbent-party Republican candidate (presumptively John McCain) by a margin of approximately 2 percentage points: $51 \%$ to $49 \%$.

\footnotetext{
${ }^{9}$ The estimates in Table 1 imply that $46.2+3.55 \cdot \overline{\Delta \ln R}=50 \%$ at $\overline{\Delta \ln R}=1.07$, where $\overline{\Delta \ln R}$ denotes the over the term weighted-average growth rate $\left(\sum_{j=0}^{14} .909^{j} \Delta \ln R_{t-j}\left(1 / \sum_{j=0}^{14} .909^{j}\right)\right)$.

${ }^{10}$ US “recessions” are designated semi- officially by the Business Cycle Dating Committee of the National Bureau of Economic Search (www.nber.org/cycles.html). Recession calls are of course ex-post, usually coming more than a half year after recessions begin.
} 
Figure 2. Realized and Hypothetical Weighted-Average Real Income Growth Rates in the Run-Up to the 2008 Election

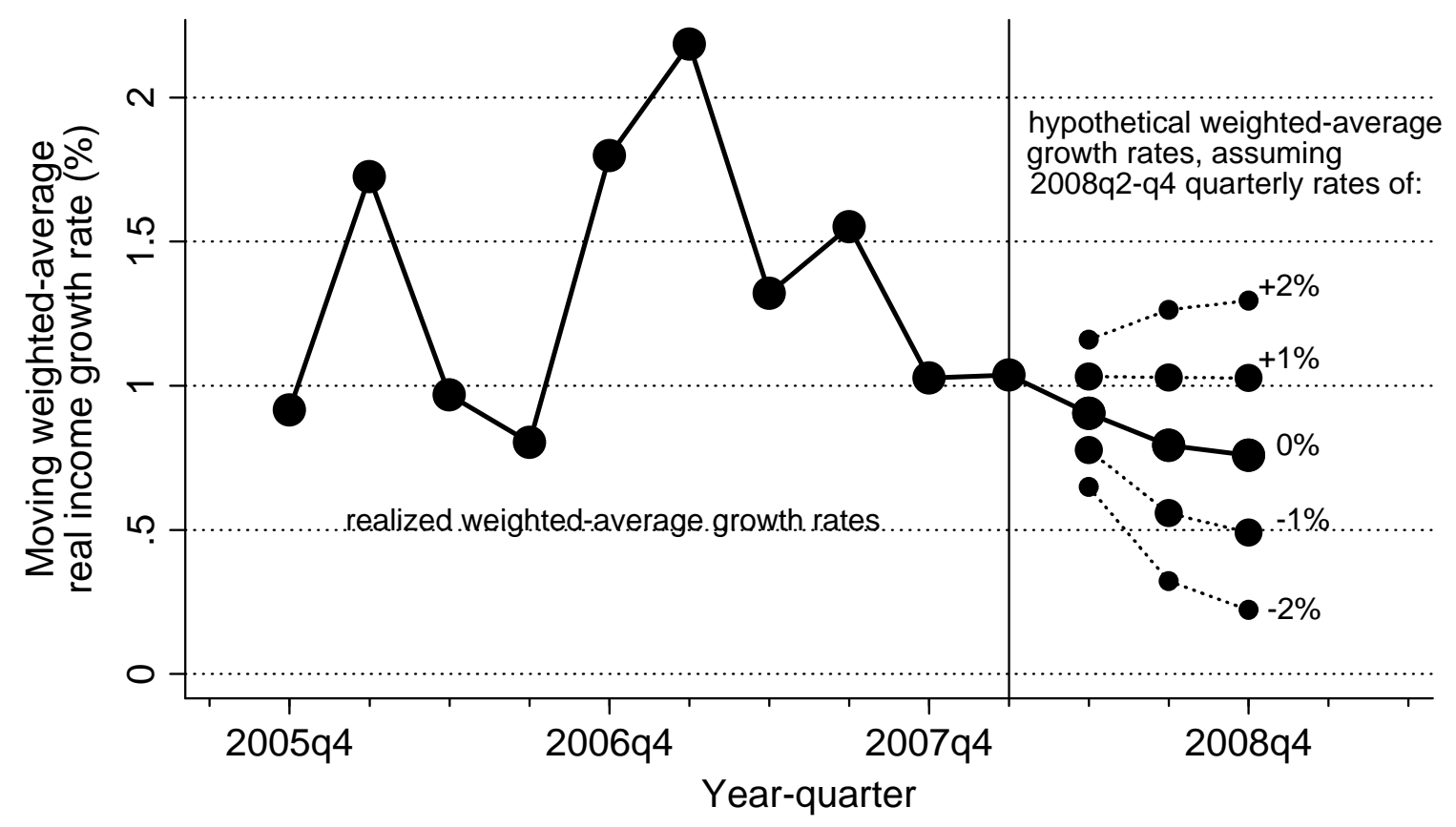

Note: Moving weighted-average growth rates of per capita real disposable personal income computed from $2005 q 4$ (3 quarters) to 2008q4 (15 quarters) using the Bread and Peace equation lag weight estimate in Table 1.

\subsection{US Military Fatalities in Iraq}

Time paths of US military fatalities in Iraq, quarter-by-quarter and cumulatively, are graphed in Figure 3. During the second half of 2007 the fatality rate turned down, falling to about 100 per quarter at the end of 2007 from rates of 200 to 300 per quarter in prior years. Contrary to some claims, it is doubtful that the decline in American fatalities has much to do with the US "surge" launched on January 10 2007, which added approximately 30,000 US troops to the effort to pacify a conflict-plagued country of nearly 30 millions. Instead, the Mahdi Army cease fire ordered by the Shia leader Muqtada al-Sadr on August 29 2007, along with the incorporation of some 80,000 or more formerly insurgent Sunni fighters to the US pacification effort (at the bargain price of $\$ 10$ per man per day plus new weaponry) are the main direct reasons for the big improvement in the rate at which US soldiers are being killed. ${ }^{11}$ Both Shia and Sunni (and Kurdish) forces appear to be biding

\footnotetext{
${ }^{11}$ (IISS 2008) describes the various factors at work from a point of view sympathetic to the American effort in Iraq that gives the 'surge' a lot more (indirect) credit than I do in reducing violence in Iraq.
} 
their time and building their strength in preparation for the civil war that many informed observers believe will inevitably break out when the US withdraws from Iraq. ${ }^{12}$

The time paths of projected fatalities during last three quarters of 2008 depicted in Figure 3 are based on the plausible (or perhaps merely the hopeful) assumptions that the Mahdi Army continues to stand down and that Sunni fighters remain in cooperative liaison with US forces. Under those assumptions cumulative US military fatalities will increase from the June 12008 level of 4,084 to about 4,300 at the time of the 2008 election.

Figure 3. US Military Fatalities in the Iraq War

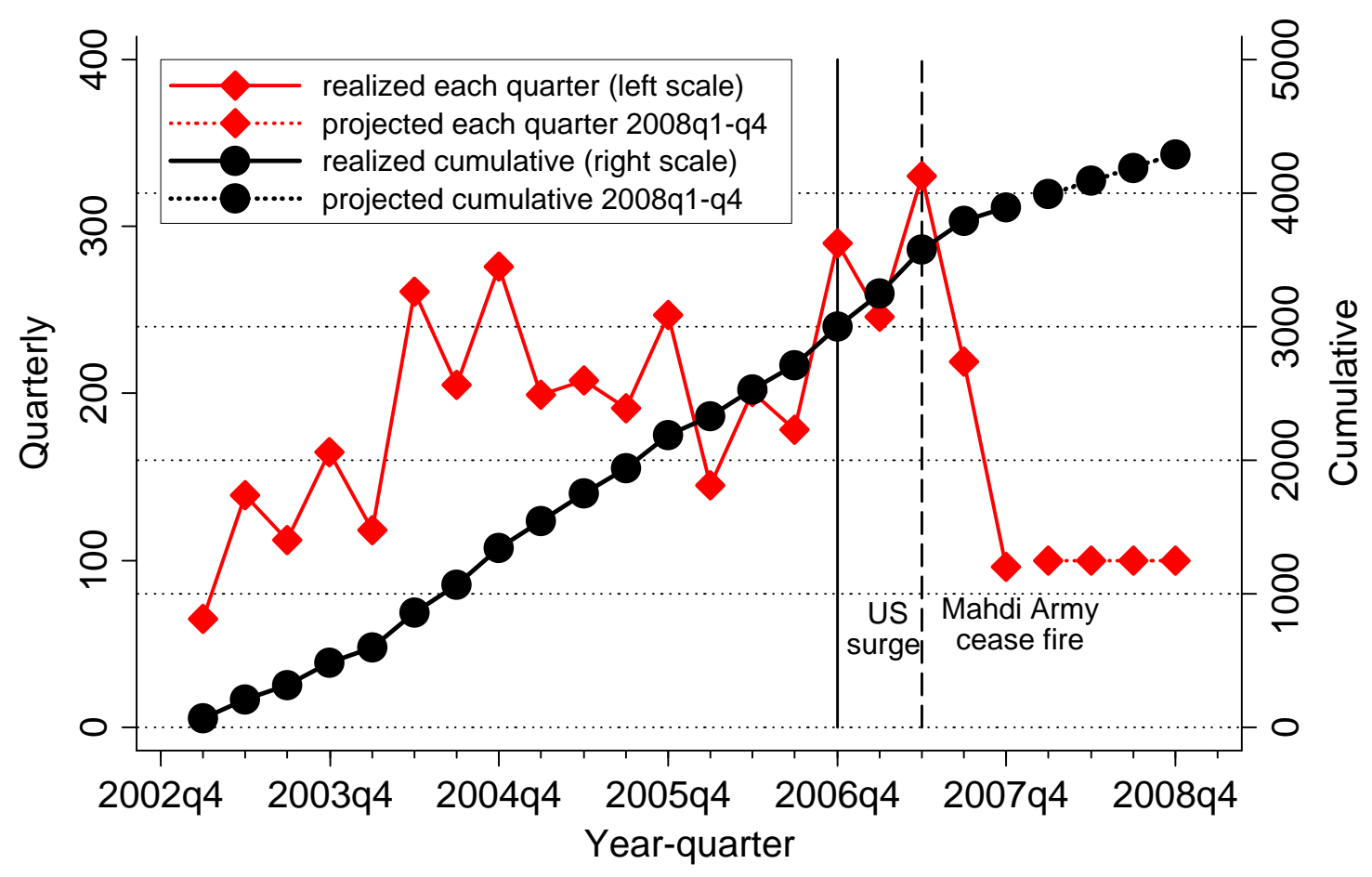

Note: Raw data from US Dept of Defense. Projected plot lines assume a fatality rate of 100 per quarter in 2008.

\section{2008 Vote Predictions from Political-Economic Fundamentals}

Table 2 shows the upshot for the presidential election result of past trends and likely developments during 2008 in real income growth and US military fatalities. The first row of the Table reports

\footnotetext{
12 The US has in effect assembled and armed a powerful sectarian force strengthening the Sunni side in the likely event of renewed civil war. See (Powers 2008) for an insightful review of this and related developments.
} 
calculations of expected votes at various 2008 real income growth rates under the counterfactual situation of zero US military fatalities in Iraq (equivalent to a 'no invasion' scenario). The counterfactual reveals the Iraq war's estimated quantitative impact on 2008 votes for president: Cumulative fatalities in the vicinity of 4,300 - the projected magnitude around Election Day depress the Republican vote by approximately three-quarters of a percentage point compared to the counterfactual benchmark of zero fatalities. An impact that size would be decisive in an election that was close on economic grounds alone. But with US fatalities in Iraq running above 4,000, the vote projections in Table 2 indicate that 2008q2-2008q4 real income growth rates need to exceed 2\% per annum for the Republicans to have a decent chance of holding the presidency. As already mentioned, growth that high seems unlikely in what shows signs of being a year of at least mild recession.

The shaded region of the Table identifies the most probable combinations of cumulative US fatalities in Iraq and weighted-average real income growth. Those political-economic fundamentals imply an expected Republican two-party vote share centered on 48.2\%. Barring unforeseen political shocks favoring the Republican candidate (presumptively John McCain), the Democratic standard bearer (presumptively Barack Obama) ought to win the 2008 presidential election by a margin in the neighborhood of 3.6 percentage points.

Table 2. Expected Two-Party Vote Shares for the Republican Candidate under Various Assumptions about US Military Fatalities in Iraq and Real Income Growth Rates in 2008

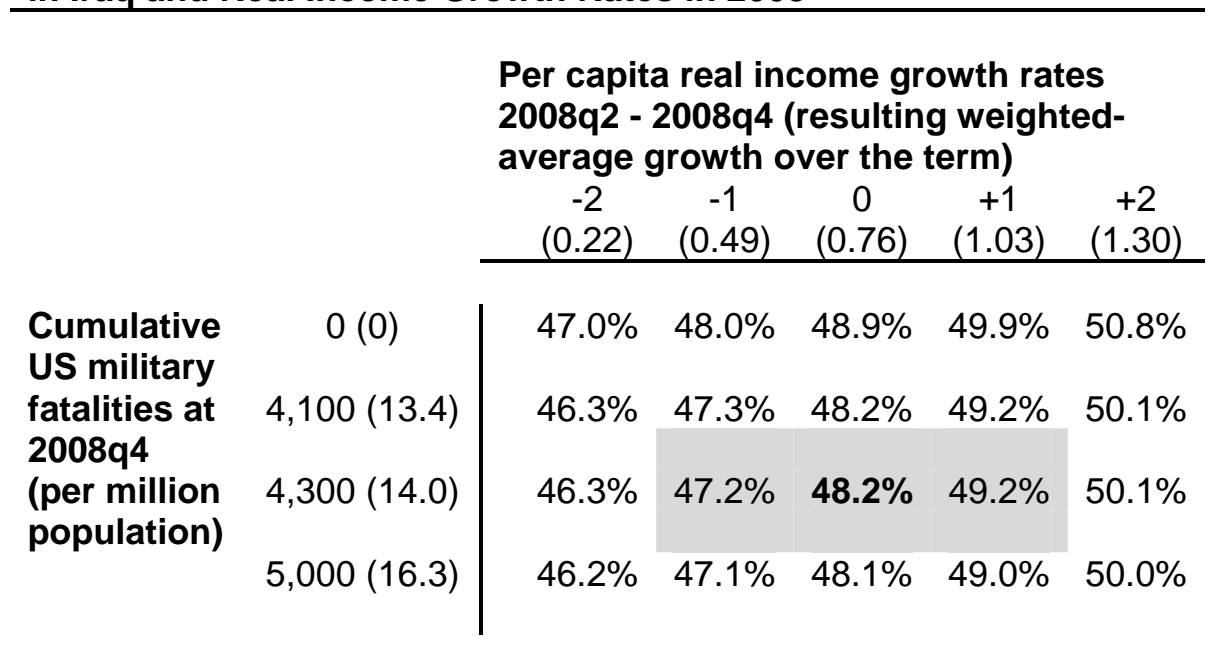




\section{Qualifications}

The Bread and Peace model aims to quantify the effects of fundamental determinants of presidential voting outcomes. However every election is affected by random, idiosyncratic factors which at times are important enough to obscure the persistent influence of fundamentals. Indeed idiosyncratic events contribute a lot of the fun to political affairs and their unexpected appearance and impact from one election to the next are why many of us follow election year developments so carefully in the media. Some obvious idiosyncrasies in the 2008 political drama pertain to the race, age and health of the contenders.

In 2008 the Democratic nominee for president presumptively will be an African-American man a first in American major party politics (as would the nomination of Hillary Clinton). Most of us would like to think that the US has matured enough that candidate race (or gender) as such are of no electoral consequence. Most of us are also realistic enough to know that this untested proposition is at best uncertain and, in fact, is probably wrong. Pure race (or gender) effects will cut both ways in 2008 but on balance they likely will hurt the Democratic Party candidate - more so Obama (the presumptive nomine ${ }^{13}$ ) than Clinton if one believes, as I do, that nowadays race prejudice substantially exceeds gender bias among US voters with a taste for discrimination.

On the Republican side are the issues of John McCain's age and health. Should he win election, McCain (b. August 29, 1936) would be the oldest first term president ever - a fact that could begin to weigh more heavily on voters than earlier as attentions get focused after the party conventions. Another episode of melanoma (McCain is known to have had three non-metastatic bouts so far) would also be a significant negative. A diagnosis of metastatic melanoma, which would be impossible to keep secret, would devastate McCain's chances producing a much lower Republican vote share than expected from fundamental factors.

\section{References}

Bartels, L. (1997). Correspondence: econometrics and elections. Journal of Economic Perspectives, 11, 195-97.

Erikson, R.S. Wlezien, C. (2008). Are Political Markets Really Superior to Polls as Election Predictors? Public Opinion Quarterly, online (May 2).

Hibbs, D.A. (1982). President Reagan's Mandate From the 1980 Elections: A Shift to the Right? American Politics Quarterly, 10(October), 387-420.

\footnotetext{
${ }^{13}$ Hillary Clinton formally conceded the nomination contest and endorsed Barack Obama on June 7 2008, a few minutes before I finished editing this article.
} 
Hibbs, D.A. (2000). Bread and Peace Voting in U.S. Presidential Elections. Public Choice, 104(1-2), 149-180.

Hibbs, D.A. (2006). Voting and the Macroeconomy. In D. Wittman and B. Weingast (Eds.), The Oxford Handbook of Political Economy (pp.565-586). Oxford, UK: Oxford University Press.

International Institute for Strategic Studies [IISS] (2008). Iraq After the Surge, Strategic Comments, 14(2), 1-2.

Nordhaus, W. (2006). Electoral Victory and Statistical Defeat? Economics, Politics, and the 2004

Presidential Election. Quarterly Journal of Political Science, 1, 313-322.

Powers, T. (2008). Iraq: Will We Ever Get Out? New York Review of Books, 55(9), 13-16.

Wlezien, C., Erikson R.S. (2004). The Fundamentals, the Polls, and the Presidential Vote. PS:

Political Science and Politics, 37(4), 747-751. 
Appendix

Table A1. Votes, Predictions and Effects of Fundamental Determinants in Presidential Elections (Fits and effects computed from the Bread and Peace equation estimates in Table 1)

\begin{tabular}{|c|c|c|c|c|c|c|c|c|}
\hline $\begin{array}{l}\text { In-party v. } \\
\text { out-party } \\
\text { candidate }\end{array}$ & $\begin{array}{l}\text { Election } \\
\text { year }\end{array}$ & $\begin{array}{l}\% \text { of two- } \\
\text { party vote } \\
\text { for } \\
\text { incumbent } \\
\text { party } \\
\text { candidate }\end{array}$ & $\begin{array}{l}\text { Predicted } \\
\% \text { vote }\end{array}$ & $\begin{array}{l}\text { Prediction } \\
\text { error }\end{array}$ & $\begin{array}{l}\text { Weighted- } \\
\text { average } \\
\text { per capita } \\
\text { real } \\
\text { income } \\
\text { growth, \% }\end{array}$ & $\begin{array}{l}\text { Real } \\
\text { income } \\
\text { growth } \\
\text { effect } \\
\text { on } \% \\
\text { vote } \\
\end{array}$ & $\begin{array}{l}\text { Cumulative } \\
\text { US military } \\
\text { fatalities } \\
\text { (per million } \\
\text { population) }\end{array}$ & $\begin{array}{l}\text { Fatalities } \\
\text { effect on } \\
\% \text { vote }\end{array}$ \\
\hline $\begin{array}{l}\text { Stevenson } \\
\text { v. } \\
\text { Eisenhower }\end{array}$ & 1952 & 44.6 & 44.8 & -0.2 & 2.4 & 8.5 & $\begin{array}{l}29,260 \\
(190.4)\end{array}$ & -10.0 \\
\hline $\begin{array}{l}\text { Eisenhower } \\
\text { v. } \\
\text { Stevenson }\end{array}$ & 1956 & 57.8 & 56.5 & 1.2 & 2.9 & 10.3 & 0 & 0 \\
\hline $\begin{array}{l}\text { Nixon v. } \\
\text { Kennedy }\end{array}$ & 1960 & 49.9 & 49.3 & 0.7 & 0.8 & 3.0 & 0 & 0 \\
\hline $\begin{array}{l}\text { Johnson v. } \\
\text { Goldwater }\end{array}$ & 1964 & 61.3 & 61.2 & 0.1 & 4.2 & 15.1 & $\begin{array}{l}218 \\
(0.9)\end{array}$ & -0.0 \\
\hline $\begin{array}{l}\text { Humphrey } \\
\text { v. Nixon }\end{array}$ & 1968 & 49.6 & 49.3 & 0.3 & 3.0 & 10.7 & $\begin{array}{l}28,896 \\
(145.6)\end{array}$ & -7.6 \\
\hline $\begin{array}{l}\text { Nixon v. } \\
\text { McGovern }\end{array}$ & 1972 & 61.8 & 59.2 & 2.6 & 3.6 & 13.0 & NA & 0 \\
\hline $\begin{array}{l}\text { Ford v. } \\
\text { Carter }\end{array}$ & 1976 & 49.0 & 50.1 & -1.1 & 1.1 & 4.0 & $\begin{array}{c}414 \\
(2.1)\end{array}$ & -0.1 \\
\hline $\begin{array}{l}\text { Carter v. } \\
\text { Reagan }\end{array}$ & 1980 & 44.7 & 44.7 & -0.0 & -0.4 & -1.5 & 0 & 0 \\
\hline $\begin{array}{l}\text { Reagan v. } \\
\text { Mondale }\end{array}$ & 1984 & 59.2 & 60.1 & -0.9 & 3.9 & 13.9 & 0 & 0 \\
\hline $\begin{array}{l}\text { GHW Bush } \\
\text { v. Dukakis }\end{array}$ & 1988 & 53.9 & 54.3 & -0.4 & 2.3 & 8.1 & 0 & 0 \\
\hline $\begin{array}{l}\text { GHW Bush } \\
\text { v. Clinton }\end{array}$ & 1992 & 46.5 & 47.7 & -1.1 & 0.4 & 1.4 & 0 & 0 \\
\hline $\begin{array}{l}\text { Clinton v. } \\
\text { Dole }\end{array}$ & 1996 & 54.7 & 49.9 & 4.8 & 1.0 & 3.7 & 0 & 0 \\
\hline $\begin{array}{l}\text { Gore v. GW } \\
\text { Bush }\end{array}$ & 2000 & 50.3 & 54.6 & -4.3 & 2.4 & 8.4 & 0 & 0 \\
\hline $\begin{array}{l}\text { GW Bush v. } \\
\text { Kerry }\end{array}$ & 2004 & 51.2 & 52.8 & -1.5 & 1.9 & 6.8 & $\begin{array}{c}1,130 \\
(3.9)\end{array}$ & -0.2 \\
\hline
\end{tabular}

